\title{
KONSEP DIRI SOSIAL PADA SISWA KELAS VII DITINJAU DARI STATUS TEMAN SEBAYA DI SMP NEGERI 1 KOTA MOJOKERTO
}

\author{
Petricha Mike Vialida ${ }^{1}$
}

\begin{abstract}
Abstrak
Hasil studi pendahuluan yang telah dilakukan oleh peneliti di SMP Negeri 1 Kota Mojokerto terdapat beberapa permasalahan perselisihan yang terjadi antar peserta didik baru kelas VII. Dampaknya adalah peserta didik yang menjadi korban cenderung menjadi pendiam saat dikelas. Kondisi tersebut memungkinkan adanya pandangan atau penilaian yang negatif tentang dirinya dalam bersosialisasi dengan teman sebayanya. Penelitian ini bertujuan untuk mengetahui bentuk konsep diri sosial peserta didik ditinjau dari status teman sebaya di kelas VII. Jenis penelitian ini adalah kualitatif dengan metode deskriptif kualitatif. Bentuk desain penelitian yang digunakan dalam penelitian ini adalah studi kasus. Alat pengumpul data yang dipakai adalah wawancara, observasi serta dokumentasi sebagai alat pelengkap. Subjek dalam penelitian ini adalah 5 peserta didik dari kelas VII di SMP Negeri 1 Kota Mojokerto yang mewakili tiap kategori status kelompok sebaya. Teknik analisis data yang digunakan adalah teknik analisis data metode alir dari Miles dan Huberman. Berdasarkan hasil analisis yang telah dilakukan dapat diketahui bahwa ada 4 peserta didik yang memiliki konsep diri sosial yang positif dan 1 peserta didik yang memiliki konsep diri sosial yang negatif. Untuk konsep diri sosial positif terdiri dari anak populer, anak terabaikan, anak kontroversial, dan anak rata-rata. Sedangkan konsep diri sosial negatif terdiri anak yang ditolak. Dari faktor penerimaan sosial sudah dapat diketahui konsep diri sosial peserta didik. Berdasarkan hasil wawancara yang telah peneliti lakukan, 4 peserta didik yang memiliki konsep diri sosial positif merasa diterima di kelas. Sehingga tidak ada masalah bagi mereka untuk berbaur dengan teman di kelas.

Kata Kunci: Konsep diri sosial, hubungan teman sebaya, status kelompok teman sebaya
\end{abstract}

\begin{abstract}
The result of preliminary study is there are some confrontation that occur among the new students of class VII. The impact is that students who become victims tend to be quiet when in class. These conditions allow for a negative view or assessment of themself in socializing with peers. From the preliminary study, the researcher want to know the form of social self-concept of learners in terms of peer relationships in class VII. This research type is qualitative design descriptive method with case study. The data collection tools used are interviews, observation and documentation as a complementary tool. The subjects in this study were 5 students from 7 th grade in 1 Public Middle School Mojokerto representing each category of peer group status. The data analysis technique is data flow analysis technique from Miles and Huberman. Based on the analysis the results are 4 learners who have positive social
\end{abstract}

\footnotetext{
${ }^{1}$ Universitas Negeri Surabaya, petrichamikevialida15@gmail.com
} 


\begin{abstract}
self-concept and 1 learner who has a negative self-social concept. For positive social self-concept consists of popular children, abandoned children, controversial children, and average children. While the negative social self-concept consists of children who are rejected. The social acceptance factors can be known the social self-concept of learners. The interviews results is 4 students who have positive social self-concept feel accepted in the classroom. Therefore there is no problem for them to mingle with friends in class.
\end{abstract}

Keywords: Social self-concept, peer relationship, peer group status

\section{PENDAHULUAN}

Sebagai upaya untuk memunculkan pola perilaku sosial yang matang maka dibutuhkan konsep diri khususnya aspek sosial yang baik pula. Staines menjelaskan ada tiga aspek dalam konsep diri, salah satunya adalah diri sosial dimana aspek ini merupakan diri sebagaimana yang diyakini individu dan orang lain yang melihat dan mengevaluasi (Burns, 1993). Berdasarkan pernyataan Staines tersebut maka konsep diri aspek sosial ini penting untuk dimiliki sebagai dasar untuk berinteraksi dengan teman dan lingkungan.

Hubungan sosial remaja merupakan hal terpenting dalam perkembangan remaja. Epstein, Brim, Blith dan Trager (Prayitno, 2006) menyatakan bahwa konsep diri yang menyangkut sosial yaitu perasaan seseorang tentang kualitas hubungan sosialnya dengan orang lain. Sehingga dapat disimpulkan bahwa konsep diri sosial erat kaitannya dengan masalah hubungan sosial individu dengan orang lain. Bonner menyatakan bahwa hubungan sosial adalah suatu hubungan antara dua individu atau lebih yang saling mempengaruhi, mengubah, atau memperbaiki kelakuan individu yang lain atau sebaliknya.

Hubungan sosial menjadi sangat penting karena remaja akan mengalami perasaan sama dengan teman sebayanya. Oleh karena itu, teman sebaya dianggap sebagai seseorang yang dapat memahaminya (Rahmawati \& Hartati, 2007). Anak belajar untuk mengenal dirinya sendiri serta kedudukannya dalam kelompok melalui hubungan interpersonal dengan teman sebaya. Dalam teori psikososial Erikson disampaikan perkembangan psikologis dihasilkan dari interaksi antara prosesproses maturasional atau kebutuhan biologis dengan tuntutan masyarakat dan kekuatankekuatan sosial yang dihadapi dalam kehidupan sehari-hari.

Teori perkembangan psikososial telah membagi ke dalam 8 tahapan perkembangan. Di mana pada usia SMP berada dalam tahapan 5 yaitu identitas vs kekacauan identitas. Pada tahap ini, seorang remaja akan mencoba banyak hal untuk mengetahui bagaimana jati diri mereka yang sebenarnya. Biasanya mereka akan melaluinya dengan teman-teman yang mempunyai kesamaan komitmen dalam sebuah kelompok. Diterima atau tidaknya remaja dalam kelompok akan berpengaruh pada konsep diri sosial yang dimiliki oleh peserta didik. Sehingga akan berpengaruh pula pada bagaimana cara peserta didik bersosialisasi dengan lingkungannya.

Terdapat 3 dimensi yang dilihat dalam penelitian ini antara lain penerimaan sosial, kecakapan sosial, dan tanggung jawab sosial. Dimensi penerimaan sosial mengacu pada persepsi sesorang untuk diterima dengan baik dan disukai oleh orang lain. Khususnya penerimaan individu dalam kelompok sebayanya serta status kepemimpinan dan popularitas mereka. Untuk dimensi kecakapan sosial dapat dipahami sebagai persepsi seseorang tentang kemampuan seseorang untuk berfungsi dalam situasi sosial. Dalam hal ini berkaitan dengan penampilan seseorang berkenaan dengan hubungan sosial, keterampilan sosial dan keramahan. Dimensi tanggung jawab sosial ini mengacu pada persepsi seseorang 
terhadap kontribusi seseorang terhadap fungsi masyarakat yang seharusnya. Adanya dimensi ini di dalam konsep diri sosial terkait dengan fakta bahwa perasaan menerima orang lain dan merasa diri mereka kompeten secara sosial tidak secara global mencerminkan persepsi seseorang tentang perkembangan sosial seseorang.

Bentuk dari konsep diri itu ada dua yaitu konsep diri positif dan konsep diri negatif. Yang pertama adalah konsep diri positif dimana dapat digambarkan dengan apabila ia merasa sebagai pribadi yang hangat, penuh keramahan, memiliki minat terhadap orang lain, memiliki sikap empati, supel, merasa diperhatikan, memiliki sikap tenggang rasa, peduli akan nasib orang lain, dan aktif dalam berbagai kegiatan sosial di lingkungannya (Nashori, 2000). Dapat konsep diri negatif apabila ia merasa tidak berminat dengan keberadaan orang lain, acuh tak acuh, tidak memiliki empati pada orang lain, tidak (kurang) ramah, kurang peduli terhadap perasaan dan nasib orang lain, dan jarang atau bahkan tidak pernah melibatkan diri dalam aktivitas-aktivitas sosial (Nashori, 2000).

Wentzel dan Asher (Santrock, 2011) menyebutkan para ahli perkembangan membedakan lima status kawan sebaya di antaranya adalah anak populer, anak terabaikan, anak ditolak, anak rata-rata dan anak kontroversial. Anak-anak populer (popular children) adalah mereka yang sering kali dipilih sebagai kawan terbaik serta jarang tidak disukai oleh kawankawannya. Anak rata-rata (average children) adalah anak yang memperoleh angka rata-rata untuk dipilih secara positif maupun negatif oleh kawan-kawannya. Anak-anak yang diabaikan (neglected children) adalah anak yang jarang dipilih sebagai kawan terbaik namun tidak ditolak oleh kawan-kawannya. Anak-anak yang ditolak (rejected children) adalah anak yang jarang dipilih sebagai kawan terbaik seseorang dan secara aktif tidak disukai oleh kawan-kawannya. Anak-anak kontroversial (controversial children) adalah anak yang mungkin dipilih sebagai kawan terbaik seseorang dan mungkin pula tidak disukai oleh kawan-kawannya.

Penelitian ini dilaksanakan di SMP Negeri 1 Kota Mojokerto. Di mana 80 persen permasalahan yang masuk ke ruang BK adalah permasalahan tentang hubungan teman sebaya. Maka dari itu, peneliti tertarik untuk mengidentifikasi lebih jauh mengenai konsep diri sosial yang dimiliki oleh peserta didik baru ditinjau dari hubungan teman sebaya. Sehingga diharapkan dapat membantu menjawab permasalahan sosial apa yang sering terjadi di sekolah, serta bagaimana cara siswa berinteraksi dengan lingkungan sosial.

\section{METODE PENELITIAN}

Penelitian ini menggunakan metode penelitian diskriptif kualitatif. Karena dalam mengkaji permasalahan, peneliti tidak membuktikan maupun menolak hipotesis yang dibuat sebelum penelitian melainkan mengolah data dan mengalisis suatu masalah secara non numerik. Data hasil penelitian ini berupa fakta-fakta yang ditemukan pada saat di lapangan oleh peneliti (Sugiyono, 2016). Penelitian ini akan menggunakan desain penelitian studi kasus. Studi kasus adalah penelitian yang mendalam tentang individu, satu kelompok, satu organisasi, satu program kegiatan, dan sebagainya dalam waktu tertentu. Data berupa hasil deskripsi yang diperoleh melalui tahap wawancara, observasi, serta dokumentasi. Subjek utama dalam penelitian ini adalah peserta didik yang populer, ditolak, diabaikan, rata-rata, dan kontroversial. Selain itu, informasi pendukung juga didapatkan dari guru Bimbingan dan Konseling.

Teknik pengumpul data yang akan digunakan dalam penelitian ini adalah wawancara, observasi, dan studi dokumentasi. Dalam penelitian ini pemeriksaan keabsahan data menggunakan menggunakan triangulasi sumber. Analisis data dalam penelitian ini menggunakan teknik analisis data metode alir dari Miles dan Huberman (Miles \& Huberman, 1992). Aktivitas dalam analisis data, yaitu 
pengumpulan data, reduksi data, penyajian data, penarikan kesimpulan, dan verifikasi.

\section{HASIL PENELITIAN \\ Anak Populer \\ Anak Populer}

Anak populer sering kali dipilih sebagai kawan terbaik dan jarang tidak disukai oleh kawan-kawannya. Hasil sosiometri yang ada menunjukkan bahwa PT mendapatkan nominasi disuka paling banyak. Berdasarkan hasil penelitian didapatkan bahwa PT dapat menampilkan prestasi yang baik di sekolah. Berikut hasil wawancara dengan PT,

"Saya sering mengikuti lomba mewakili sekolah. Saya dipilih oleh sekolah, Bu. Karena saya pas seleksi masuk SPENSA menggunakan jalur prestasi. Jadi diambil dari situ." (I.PT.W.19.04.18)

Hal itu diperkuat oleh pernyataan guru BK sebagai berikut,

"Kalau di kelas PT itu ketua kelas. PT biasanya ikut lomba pidato dan karya ilmiah.” (I.PR.W.20.04.18)

Berdasarkan dua petikan wawancara diatas dapat diambil kesimpulan jika PT menunjukkan prestasi yang cemerlang di sekolah. Selain itu PT juga termasuk pribadi yang supel. Berikut hasil wawancara dengan guru BK,

"Kalau di luar kelas ya naik keterampilan sosialnya."

(I.PR.W.20.04.18)

Hal tersebut diperkuat dengan hasil observasi bahwa PT memiliki banyak teman di luar kelas baik dengan teman seangkatan maupun dengan kakak kelas. Karena PT aktif menjadi anggota OSIS dan berbagai kegiatan lomba berkelompok serta ekstrakurikuler. Berdasarkan penjelasan diatas dapat disimpulkan bahwa PT memiliki konsep diri sosial yang positif.

\section{Anak Rata-Rata}

Anak rata-rata adalah anak yang memperoleh angka rata-rata untuk dipilih secara positif maupun negatif oleh temantemannya. Hasil sosiometri menunjukkan bahwa SD mendapatkan nominasi yang hampir seimbang antara yang disuka dan tidak disuka. Berdasarkan hasil penelitian SD termasuk anak yang memiliki konsep diri sosial yang positif. SD termasuk anak yang supel berikut hasil wawancara dengan $\mathrm{SD}$,

\section{"Saya sama teman itu biasa saja Bu" (I.SD.W.17.04.18)}

Hal itu diperkuat oleh pernyataan Guru BK sebagai berikut,

"Dia bisa berbaur dengan baik. SD termasuk tipe anak yang bisa berbaur" (I.JD.W.20.04.18)

Selain hasil wawancara tersebut, diperkuat pula dengan hasil observasi yang menunjukkan bahwa SD bermain dengan teman sekelas dan lain kelas saat istirahat berlangsung. SD juga aktif mengikuti kegiatan ekstrakurikuler selain yang diwajibkan sekolah, yaitu basket. SD pun juga mengikuti lomba antar kelas mewakili kelasnya. Sehingga dapat disimpulkan bahwa SD memiliki konsep diri sosial yang positif.

\section{Anak Diabaikan}

Anak yang diabaikan adalah anak yang jarang dipilih sebagai kawan terbaik namun tidak ditolak oleh kawan-kawannya. Berdasarkan hasil sosiometri menunjukkan bahwa NA memiliki nominasi disuka paling sedikit tetapi tidak ada teman yang memberikan nominasi tidak suka kepadanya. NA memiliki prestasi yang baik di sekolah. Data yang didapatkan di lapangan adalah,

"Saya pernah mengikuti lomba olimpiade matematika tingkat SMP, Bu." (I.NA.W.17.04.18)

NA termasuk anak yang supel dan aktif. Berikut hasil wawancara, 
"Mau berteman dengan saya atau nggak itu urusan mereka, kalau saya sih berteman saja, Bu." (I.NA.W.17.04.18)

Hal itu juga diperkuat oleh pernyataan Guru BK,

"Kalau saya amati ya dia bisa berteman dengan teman-temannya. Bisa berbaur begitu. Meskipun keliatannya diam tetapi dia anak yang percaya diri." (I.JD.W.20.04.18)

Berdasarkan hasil observasi NA juga aktif memberikan pendapat saat kerja kelompok. Selain itu, NA juga mengikuti 2 kegiatan ekstrakurikuler di sekolah selain yang diwajibkan oleh sekolah. Sehingga dapat disimpulkan bahwa meskipun NA termasuk anak yang diabaikan di kelas, NA masuk dalam kategori anak yang memiliki konsep diri sosial positif.

\section{Anak Kontroversial}

Anak kontroversial mungkin dipilih sebagai kawan terbaik seseorang dan mungkin pula tidak disukai oleh kawankawannya. Secara sosiometri, kelompok ini unik karena anak kontroversial tinggi dalam penerimaan dan penolakan. Hal ini sama dengan hasil sosiometri yang telah disebar dimana subjek terpilih karena memiliki nominasi yang sama antara disuka dan tidak disuka. Berdasarkan hasil penelitian menunjukkan bahwa TA pribadi yang penuh keramahan dan memiliki minat terhadap orang lain. Berikut adalah fakta yang didapatkan di lapangan,

"Saya merasa diterima, Bu. Tapi ada satu atau dua orang yang tidak suka sama saya." (I.TA.W.19.04.18)

Berikut didukung oleh pernyataan dari Guru BK kelas TA,

"Kalau menurut saya TA tidak memiliki kesulitan saat harus berbaur di kelas. Kalau saya menilai ada yang suka dengan TA, ada juga yang tidak. Akan tetapi kalau di kelas TA tidak memiliki
permasalahan berarti dalam hal
berbaur dengan
(I.DV.W.20.04.18)

Dapat ditarik kesimpulan bahwa TA merupakan pribadi yang ramah sehingga tidak ada kesulitan untuknya berbaur dengan temannya. Selain itu TA juga termasuk anak aktif yang mengikuti kegiatan baik di sekolah maupun di luar sekolahnya. TA aktif dalam kegiatan tari, modelling, serta Gus Yuk Mojokerto. Di sekolah dia juga aktif sebagai anggota OSIS sehingga memiliki teman dari berbagai kalangan. TA juga mengikuti 2 kegiatan ekstrakurikuler di luar yang diwajibkan oleh sekolah. Berdasarkan pemaparan diatas dapat disimpulkan bahwa TA termasuk anak yang memiliki konsep diri sosial yang positif.

\section{Anak Ditolak}

Anak yang ditolak jarang dipilih sebagai kawan terbaik seseorang dan secara aktif tidak disukai oleh kawan-kawannya. Hasil sosiometri menujukkan bahwa AP mendapatkan nominasi tidak disuka terbanyak. Berdasarkan hasil penelitian AP termasuk anak yang memiliki konsep diri sosial yang negatif. Hal ini sesuai dengan ciri-ciri bentuk sikap konsep diri sosial negatif yaitu kurang ramah. Berikut wawancara dengan AP yaitu,

"Saya tidak diterima di kelas Bu. Saya kesulitan mencari teman untuk dijadikan kelompok tugas. Temanteman juga agak menjauh Bu." (I.AP.W.18.04.18)

Saat wawancara berlangsung, AP menjawab dengan menangis. Hal itu juga diperkuat oleh pernyataan Guru BK,

"Di kelas dia tidak ada temannya. AP kurang baik dalam bersosialisasi. Soalnya ya itu tadi dek, kan temannya itu-itu saja." (I.PR.W.20.04.18)

Berdasarkan hasil observasi juga didapatkan bahwa AP hanya duduk 
menyendiri di bangku belakang. Saat kerja kelompok pun AP lebih banyak diam tidak memberikan tanggapan maupun pendapat. AP pun jarang mengikuti kegiatan di sekolahnya. Misalnya, AP hanya mengikuti kegiatan ekstrakurikuler yang diwajibkan oleh sekolah. Sehingga dapat disimpulkan bahwa AP memiliki konsep diri sosial yang negatif.

\section{KESIMPULAN}

Penelitian ini dilakukan untuk memberikan gambaran mengenai bentuk konsep diri sosial pada siswa kelas VII ditinjau dari status teman sebaya di SMP Negeri 1 Kota Mojokerto. Wentzel dan Asher (dalam Santrock, 2007) menyebutkan para ahli perkembangan membedakan lima status teman sebayanya. Kategori tersebut antara lain anak yang populer, anak yang diabaikan, anak yang ditolak, anak yang kontroversial dan anak yang rata-rata. Penentuan subjek tersebut diperoleh melalui hasil sisometri yang telah disebar. Untuk mengetahui bentuk konsep diri sosial akan diamati melalui aspek dimensi konsep diri sosial. Dimensi konsep diri sosial yang akan diteliti adalah penerimaan sosial, kecakapan sosial, serta tanggungjawab sosial.

Hasil penelitian yang dilakukan menunjukkan bahwa setiap kategori teman sebaya yang ada memiliki perbedaan bentuk konsep diri sosial dalam dirinya. Berdasarkan hasil analisis yang telah dilakukan terdapat 4 peserta didik yang memiliki konsep diri sosial yang positif serta ada 1 peserta didik yang memiliki konsep diri sosial yang negatif. Untuk konsep diri sosial positif terdiri dari anak populer, anak terabaikan, anak kontroversial, dan anak rata-rata. Sedangkan konsep diri sosial negatif terdiri anak yang ditolak. Berdasarkan hasil wawancara yang telah peneliti lakukan, 4 peserta didik yang memiliki konsep diri sosial positif merasa diterima di kelas. Sehingga tidak ada masalah bagi mereka untuk berbaur dengan teman di kelas. Meskipun ada satu atau dua anak yang tidak suka dengan mereka itu masih dalam batas yang wajar.
Dari penelitian yang telah dilakukan, peneliti dapat memberikan saran sebagai berikut:

\section{Konselor Sekolah atau Guru BK}

Penelitian ini diharapkan dapat dijadikan konselor atau guru BK sebagai tambahan informasi untuk memberikan layanan yang lebih kompleks dan menyeluruh bagi peserta didik yang ada di sekolah.

\section{Pihak Sekolah}

Hasil dari penelitian ini diharapkan dapat dijadikan sebagai tambahan informasi bagi sekolah dalam pelaksanaan program bimbingan dan konseling sekolah.

\section{Peneliti Lain}

Hasil dari penelitian ini dapat dijadikan sebagai referensi dalam melakukan penelitian sejenis yang lainnya. Sehingga hasil yang selanjutnya dapat lebih melengkapi dan menyempurnakan penelitian yang sebelumnya.

\section{DAFTAR PUSTAKA}

Burns, R. B. (1993). Konsep Diri: Teori, Pengukuran, Perkembangan dan Perilaku. Jakarta: Acan.

Miles, M. B., \& Huberman, A. M. (1992). Analisis Data Kualitatif. Jakarta: UI Press.

Nashori, F. (2000). Agenda Psikologi Islami. Yogyakarta: Pustaka Pelajar.

Prayitno, E. (2006). Psikologi Perkembangan Remaja. Padang: FIP UNP.

Rahmawati, F. D., \& Hartati, R. S. (2007). Penyesuaian Sosial Remaja Berbakat dalam Menjalin Hubungan Persahabatan. Gifted Review: Jurnal Keberbakatan \& Kreativitas, 1(1), 34-35.

Santrock, J. W. (2011). Life Span Development (5th ed.). Jakarta: Erlangga.

Sugiyono. (2016). Memahami Penelitian Kualitatif. Bandung: Alfabeta. 